\title{
Effect of uncertainty in land use, damage models and inundation depth on flood damage estimates
}

\author{
H. de Moel · J. C. J. H. Aerts
}

Received: 15 February 2010/Accepted: 23 November 2010/Published online: 12 December 2010

(C) The Author(s) 2010. This article is published with open access at Springerlink.com

\begin{abstract}
With the recent transition to a more risk-based approach in flood management, flood risk models—being a key component in flood risk management—are becoming increasingly important. Such models combine information from four components: (1) the flood hazard (mostly inundation depth), (2) the exposure (e.g. land use), (3) the value of elements at risk and (4) the susceptibility of the elements at risk to hydrologic conditions (e.g. depth-damage curves). All these components contain, however, a certain degree of uncertainty which propagates through the calculation and accumulates in the final damage estimate. In this study, an effort has been made to assess the influence of uncertainty in these four components on the final damage estimate. Different land-use data sets and damage models have been used to represent the uncertainties in the exposure, value and susceptibility components. For the flood hazard component, inundation depth has been varied systematically to estimate the sensitivity of flood damage estimations to this component. The results indicate that, assuming the uncertainty in inundation depth is about $25 \mathrm{~cm}$ (about $15 \%$ of the mean inundation depth), the total uncertainty surrounding the final damage estimate in the case study area can amount to a factor 5-6. The value of elements at risk and depth-damage curves are the most important sources of uncertainty in flood damage estimates and can both introduce about a factor 2 of uncertainty in the final damage estimates. Very large uncertainties in inundation depth would be necessary to have a similar effect on the uncertainty of the final damage estimate, which seem highly unrealistic. Hence, in order to reduce the uncertainties surrounding potential flood damage estimates, these components deserve prioritisation in future flood damage research. While absolute estimates of flood damage exhibit considerable uncertainty (the above-mentioned factor 5-6), estimates for proportional changes in flood damages (defined as the change in flood damages as a percentage of a base situation) are much more robust.
\end{abstract}

Keywords Floods - Flood risk - Flood damage - Flood damage assessment · Uncertainty $\cdot$ Sensitivity

H. de Moel $(\bowtie) \cdot$ J. C. J. H. Aerts

Institute for Environmental Studies, VU University Amsterdam,

De Boelelaan 1085, $1081 \mathrm{HV}$ Amsterdam, The Netherlands

e-mail: hans.de.moel@ivm.vu.nl 


\section{Introduction}

Flood damages are responsible for approximately one-third of the economic losses incurred as a result of natural hazards in Europe and are, together with wind storms, the most frequently occurring natural disaster (Munich Re 2005; EEA et al. 2008). In recent decades, a substantial increase in flood damages can be observed, which has mainly been attributed to increased developments in flood-prone areas (Munich Re 2005). As floodprone areas continue to be developed, the potential damages as a result of floods will continue to rise. In addition, future climate change may increase flood frequencies and magnitudes and further increase flood damages (te Linde et al. 2010). Because of these trends and uncertainties, flood management is moving towards a more risk-based approach in Europe (DKKV 2004; Tunstall et al. 2004; Roos and Van der Geer 2008) instead of relying mainly on protection standards. This change to risk management is also recognised and supported by the EU, who have adopted a flood directive (2007/60/EC) stating that member countries have to create flood risk maps (see e.g. de Moel et al. 2009) and draw up (basin-wide) flood risk management plans.

In such an approach, flood risk managers need apart from information on the hydrological hazard, also detailed information on possible consequence of a flood. Such information can then be used for various purposes, for instance, to define high-risk areas (for prioritisation of extra measures), assess benefits (e.g. avoided damage) for cost-benefit analyses or to set up insurance or compensation schemes. In order to assess possible consequences of a flood, several flood damage models have been developed in Europe. These models generally focus on quantifying flood damages in monetary terms (Kok et al. 2005; Hall et al. 2005a; IKSR 2001; Thieken et al. 2008). Meyer and Messner (2005) have evaluated flood damage assessment methods employed in the United Kingdom, the Netherlands, the Czech Republic and Germany. They show that, while the methods differ in various details, they all follow the same concept using four components with information underpinning the damage estimate (see also Messner et al. 2007): (1) hydrological characteristics, mostly represented by flood depth, (2) elements at risk, often estimated using land use or individual buildings, (3) value of elements at risk and (4) susceptibility of the elements at risk to the hydrological characteristics, usually defined using depth-damage curves.

In North-Western Europe, various methods have been developed to assess flood damages at various scales. In the United Kingdom, the 'multi-coloured manual' (PenningRowsell et al. 2005), which consists of a large set of stage-damage curves created by flood experts (synthetic curves), is the most commonly used for flood damage modelling (i.e. Hall et al. 2005a). In Germany, on the other hand, empirical data on flood losses are often used, like the HOWAS21 database, containing several thousand historical records of flood damage to different buildings (see e.g. Merz et al. 2004). The above-mentioned data are used, for instance, in the method employed by the International Commission for the Protection of the Rhine (ICPR) for the Rhine Atlas (IKSR 2001). More recently, a damage model using survey data from the 2002 floods has been developed in Germany, taking into account building quality, contamination and precaution measures (Thieken et al. 2008). In Flanders (Belgium), Vanneuville et al. (2006) have created a method to assess damages largely based on land-use types plus a limited number of additional point data. In the Netherlands, the so-called standard-method (HIS-SSM) is used to calculate flood damages, which combine land-use and building data on various spatial scales with synthetic damage curves (Kok et al. 2005). Similar flood damage models have been developed in other parts of the world like the USA (see e.g. USACE 2007), Japan (Dutta et al. 2003), Thailand 
(Lekuthai and Vongvisessomjai 2001; Tang et al. 1992) and Brazil (Nascimento et al. 2006).

Uncertainty exists in all four sources of information because of generalisations, assumptions and aggregation of information, which propagates through the model calculations to accumulate in the final damage estimate (see e.g. Heuvelink 1998). Uncertainty concerning the hydrological characteristics can be attributed to generalisations in parameterisations and input data constraints within numerical models. The elements at risk are often represented by low-resolution land-use maps with a limited number of land-use classes, which greatly generalise the real situation. Linked to the elements at risk, the value of these elements is also compounded by these generalisations resulting from a limited amount of land-use classes. Even if the amount of classes would not be limited, there would still be further generalisations because of spatial differences, temporal differences (market fluctuations), and different methods to valuate elements at risk. The susceptibility of elements at risk is usually described using so-called depth-damage curves (Smith 1994; Merz et al. 2007). These curves relate potential flood damages for a particular building type or land-use class to flood depth, again generalising the real situation and often excluding other hazard related factors such as flood duration and flow velocity. Such curves can be created synthetically by experts (see e.g. Veerbeek and Zevenbergen 2009; PenningRowsell et al. 2005) or can be derived from empirical data of historical flood events (see e.g. Merz et al. 2004; Thieken et al. 2008).

Existing flood damage assessment studies (e.g. RWS-DWW 2005; Hall et al. 2005a) acknowledge that flood damage estimates feature a degree of uncertainty, but most efforts to assess or cope with this uncertainty have focused on one of the components of the assessment-in most cases, the hydrological component. For instance, in the Dutch FLORIS study (RWS-DWW 2005) upper and lower estimates for potential flood damages are based on different inundation scenarios. Similarly, Apel et al. (2006) consider uncertainties from flood frequency statistics and spatial levee breach scenarios using a probabilistic framework. In another study, Apel et al. (2004) assessed various sources of aleatory (natural variability) and epistemic (incomplete knowledge) uncertainty in an economic risk analysis, and while they took many sources into account, all were related to the hydrological component. Other studies that looked into uncertainties in the hydrological component include Hall et al. (2005b) and Noack and Yörük (2008).

Recently, there have been a couple of studies focusing on uncertainty in the value and/or susceptibility of elements at risk. One has been carried out by Merz et al. (2004), who evaluated the existing empirical relationships between inundation level and flood damage to buildings and found that there is considerable uncertainty in the damage functions that are internationally accepted as the standard method of deriving flood damages (Merz et al. 2007; Smith 1994). Another study has been performed by Egorova et al. (2008), who assessed uncertainties in the value of elements at risk and developed a methodology to incorporate uncertainties in depth-damage curves. To our knowledge, no study has reported on the influence of uncertainty in land-use maps on flood damage estimates.

Several authors have used various damage models or curves to illustrate the uncertainty in flood risk estimates (Merz and Thieken 2009; Apel et al. 2008; Meyer et al. 2009). Apel et al. (2008) and Merz and Thieken (2009) also included uncertainty related to the inundation depth and flood probability. Both show that for extreme events, the estimation of the probability contributes the most uncertainty.

The main goal of this research is to assess the uncertainty surrounding flood damage estimates and relate this uncertainty to the four information sources underpinning flood damage models (inundation depth, land use, value of elements at risk and depth-damage 
curves). This research focuses on uncertainty in flood damage estimates, rather than flood risk (i.e. probability times damage). Hence, uncertainty surrounding the estimation of the probability of an event is not addressed. We use different land-use maps to illustrate uncertainty related to the estimation of elements at risk and different damage models to estimate uncertainty related to the value and susceptibility of elements at risk. Inundation depth will be varied manually in order to assess the sensitivity of the damage estimate to this component, which can then be compared with the effect of the other three components. This approach will be applied to a case study area in the south of the Netherlands.

This paper is organised as follows. Section 2 introduces the case study area, and Section 3 describes the methodology, including the manner in which the four components of the damage assessment are varied. Section 4 explains the flood damage calculations resulting from the variations in these components and charts the source of uncertainty in the components. Section 5 wraps up the results and evaluates the effect of uncertainty inherent in the components on the damage estimate.

\section{Case study area}

The Netherlands is a densely populated and industrialised country in North-Western Europe and is located in the delta of the rivers Meuse, Rhine and Scheldt. Large parts of the country are situated at elevations below mean sea- or river water levels. These lowlying areas are protected by a system of dikes, dunes and other protective structures that form closed geographical units called dike rings. The embankments protecting each dike ring are designed to withstand extreme flood events with a specific return period $(1 / 1,250$; $1 / 2,000 ; 1 / 4,000 ; 1 / 10,000)$. The case study area is a dike ring (number 36 ) located in the south of the Netherlands: Land van Heusden/Maaskant (Fig. 1), which has a protection level of 1/1,250 years. This dike ring area measures about $740 \mathrm{~km}^{2}$ and is mainly used for agriculture $(\sim 80 \%)$ but also features key infrastructure such as highways and railroads as well as the cities of Den Bosch ( 140,000 inhabitants) and Oss ( 75,000 inhabitants). All these assets are vulnerable to flooding in case of a failure of flood embankments.

\section{Methodology}

\subsection{Approach}

In this study, we specifically look at the influence of all four components on the sensitivity and uncertainty of the total damage estimate. This is done by manually varying the components in a 'one factor at a time' approach. The basic model we use to calculate flood damages is based on depth-damage functions which relates the inundation depth in a grid cell to a fraction of the total value at risk of the corresponding land use. This fraction (usually named ' $\alpha$ ' or 'damage factor') is then multiplied with the total value that can get damaged (also based on the land use) to derive a flood damage estimate (Fig. 2).

Below, we will describe the four components and how they have been varied. Components 3 and 4, depth-damage curves and the value of elements at risk, are derived from three meso-scale damage models (DMs) that make use of land-use information to estimate flood damages and have been employed in low-lying areas in North-Western Europe. These models are as follows: 
Fig. 1 Map of the case study area in the Netherlands on the south bank of the river Meuse
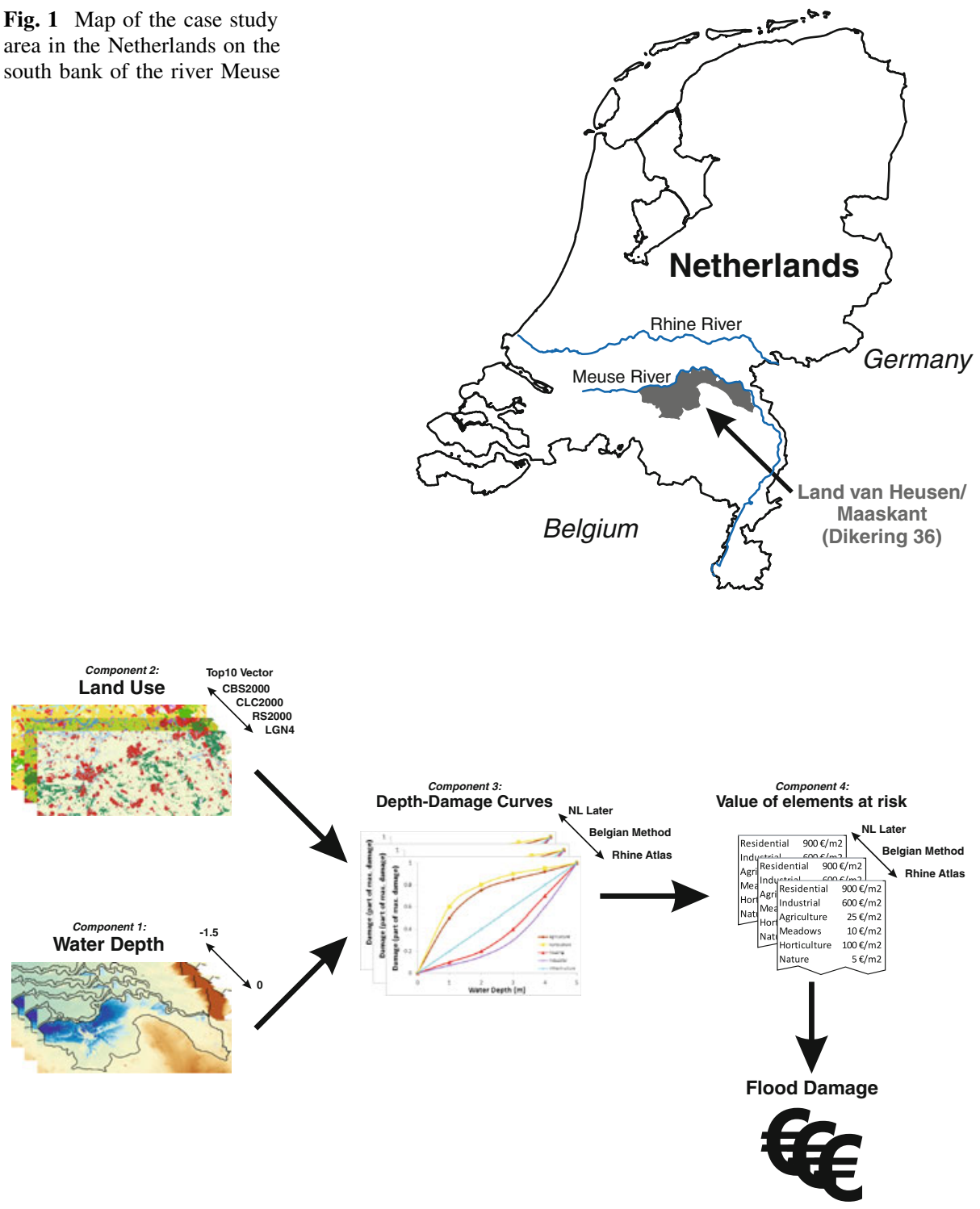

Fig. 2 Flow diagram of the methodology, showing the four components and how they are varied in this study

- (DM1) The Rhine Atlas, developed by the International Commission for the Protection of the Rhine (ICBR 2001).

- (DM2) A method created for the Flemish Environmental Agency (Vanneuville et al. 2006).

- (DM3) The Netherlands Later (NL Later) method (Klijn et al. 2007).

As depth-damage curves and the value of elements at risk are designed to be used together, we accordingly use depth-damage curves with the corresponding value of 
elements at risk of the same DM. Both have, however, their own sources of uncertainty and will therefore be discussed separately.

\subsection{Component 1: Inundation depth}

Various hydrological factors affect the magnitude of flood damage. These include flood extent, inundation depth, flow velocity (in steep catchments or near breaches in embankments), duration and timing of a flood. Such parameters can be computed using hydrological and hydrodynamic models (see e.g. de Moel et al. 2009). For flood damages, inundation depth is regarded as the most important parameter (Aerts et al. 2008; Merz et al. 2007; Wind et al. 1999), especially in the situation of dike ring 36 (Bouwer et al. 2009). As a result, it is mainly this parameter that is used in damage assessments, including our approach. We do note, however, that flood duration may have a considerable effect on flood damages, especially indirect damages due to business disruption. In this study, however, we focus mainly on direct damages.

Flood extent and flood depth are usually calculated for a flood event with a specific return period (see e.g. de Moel et al. 2009). As the dikes that protect dike ring 36 are designed for very high return periods, the probability of floods overtopping the dikes is very low. Recent studies, however, point to the possibility that dikes may fail during less extreme floods with higher recurrence periods (Brinke and Bannink 2004; RWS-DWW 2005). Such a dike failure may develop, for example, due to groundwater pressure underneath a dike or piping effects within a dike. Therefore, we concentrate on floods related to dike breaches rather than overtopping. We use the 42 breach scenarios created by Bouwer et al. (2009), each represented by a map showing inundation levels per grid cell of $25 \times 25 \mathrm{~m}^{2}$. These 42 breach scenarios have been further processed into one aggregated map showing the maximum inundation depth per grid cell across all scenarios. The map displays inundation depths ranging from zero to five metre with an average of $1.77 \mathrm{~m}$ and a standard deviation of $1.07 \mathrm{~m}$ and is further referred to as the "base inundation depth map" (Fig. 3). Use is made of an aggregated map because we aim to assess the effect of uncertainty in inundation depth information, rather than different inundation scenarios, on the resulting damage estimates. As a result, uncertainties related to probabilities of flooding (and correspondingly flood risk) are not taken into account in this study.

In order to assess the effect of inundation depth on the damage estimate, we have incrementally adjusted the base map. By comparing this sensitivity to the effect of uncertainty in the other two components, it is possible to derive how large the uncertainty in the inundation depth would have to be in order to have the same effect as each of the other two components on the final damage estimate. As it concerns a polder area, it is assumed that the inundation depth cannot go higher (as otherwise water would flow out of the polder again). The inundation depth has therefore been incrementally lowered down to $-150 \mathrm{~cm}$ at small intervals $(5 \mathrm{~cm})$. This way, also a reduction in inundated area, is taken into account. Because there is no information on any spatial distribution or autocorrelation of uncertainty in this inundation map, all adjustments from the base inundation map were kept equal for the entire area.

\subsection{Component 2: Land use}

At the most detailed level, flood damage potential can be derived from information on individual assets (e.g. buildings, vehicles) (e.g. Lekuthai and Vongvisessomjai 2001; Kok et al. 2005). At the regional or national scale, land use is often used as an indicator for 


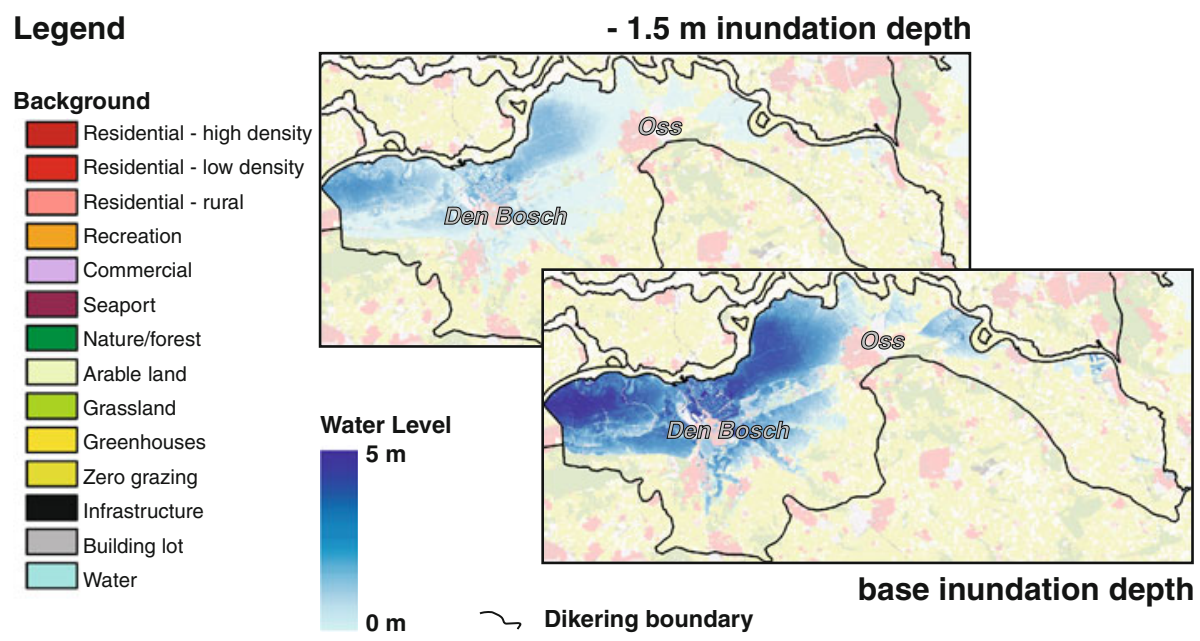

Fig. 3 Maps of the case study area superimposed on the Land Use Scanner land use (for 2000), showing the contours of the dike rings and the inundation depth

potential flood damage (e.g. IKSR 2001; Hall et al. 2005a; Klijn et al. 2007). In this regional study, we use land use as the principal factor for defining flood damage exposure.

Variations across such land-use databases exist as they have been derived from different sources (aerial photography or satellite imagery). Furthermore, they have been classified into land-use classes using different algorithms by different experts. We use this variation across different land-use databases as an indication for the uncertainty inherently present in land-use data. Hence, land-use data for the dike ring 36 area is taken from five sources: CORINE, LGN4, CBS, Top10 and the Land Use Scanner (Table 1). The CORINE database is a pan-European database based on a standardised classification of satellite imagery (EEA 2007). The LGN4 is a raster data set that focuses on the green environment. It distinguishes many different agricultural and natural land-use types (de Wit and Clevers 2004; de Wit 2003; van Oort et al. 2004). Contrary to the LGN4, the CBS land-use data set focuses more on the built environment and distinguishes different residential classes (CBS 2000). The Top10 data set also focuses on the built environment, particularly residential, and recognises individual buildings and many different types of roads and objects (Kadaster 2005). The last source of land-use information used in this analysis comes from the Land Use Scanner (LUS), a spatial model developed to project future land use

Table 1 Different sources of land-use information used in this study and their characteristics

\begin{tabular}{llllll}
\hline Land-use database & Year & No. of classes & Resolution & Type & Producer \\
\hline CORINE (CLC) & 2000 & 44 & $100 \times 100 \mathrm{~m}^{2}$ & Raster & European Environmental Agency \\
LGN4 & $1999 / 2000$ & 40 & $25 \times 25 \mathrm{~m}^{2}$ & Raster & Environmental Research Institute \\
CBS & 2000 & 38 & $1: 10.000$ & Vector & Dutch Statistics Bureau \\
Top10 & 2003 & Hundreds & $1: 10.000$ & Vector & Bureau for Topography \\
Land Use & 2000 & 15 & $100 \times 100 \mathrm{~m}^{2}$ & Raster & Environmental Assessment \\
$\quad$ Scanner (LUS) & & & & Agency \\
\hline
\end{tabular}


(Hilferink and Rietveld 1999). In our analysis, we have used their base land-use map for 2000 (Riedijk et al. 2007).

\subsection{Components 3 and 4: Damage models}

In order to determine the uncertainty in flood loss estimations due to differences in depthdamage curves and total value at risk, we estimate flood damages using three different damage models (DMs). Similar to the land-use data, the variation between the damage models is regarded as an indication of the uncertainty inherently present in depth-damage functions and values of elements at risk. The three DMs differ in their assumption on the value of elements at risk per land-use type, the number of land-use types and the shape of the depth-damage curve.

In order to compare flood damage estimates using the three DMs, the land-use classes of the different land-use maps had to be aggregated in order to get the amount of classes distinguished by the DMs (Rhine Atlas, DM1: 6 land-use classes; Flemish method, DM2: 11 land-use classes; NL later method, DM3: 14 land-use classes). The values of elements at risk for these classes have directly been taken from the corresponding DM, regardless of land-use map. By doing this, the total value at risk in the dike ring can be different between land-use maps because of different proportions of the different land-use types. It is possible to correct for this by calculating a fixed total value at risk and disaggregating this over the available land-use classes, as done by Wünsch et al. (2009). Both the derivation of the total value at risk and the disaggregation can be done in several ways and would quickly increase the amount calculations needed for comparison. As Wünsch et al. (2009) found that the influence of the different disaggregation methods is relatively small and mainly exposes the characteristics of a flood model at varying degrees; we did not take disaggregation techniques into account.

Another complication is the number of residential classes distinguished within each DM. Both DM2 and DM3 distinguish three residential classes where DM1 has only one residential class. The residential classes in DM2 and DM3 only differ in their value of elements at risk and not so much in the shape of their corresponding depth-damage curves. Subsets of DM2 and DM3 with one and two residential classes were therefore created by recalculating the values of elements at risk. Similarly, subsets of land-use maps distinguishing more than one residential class have also been created by aggregating the residential classes to two (dense and medium dense aggregated into one class) and one (all residential cells) residential class.

\subsubsection{Rhine Atlas (DM1)}

The Rhine Atlas method (ICBR 2001) originally uses the CORINE land-cover data set and distinguishes six damage categories. For three land-use types (residential, industry and infrastructure) an immobile (real estate) and mobile (e.g. household goods) damage category is distinguished. Depth-damage curves (Fig. 4) and figures for the total value of elements at risk (Table 2) have been derived using data from the German HOWAS database and experts from different sectors and countries. The values of elements at risk are based on market values (as opposed to replacement values). Damage to vehicles, indirect damages, and costs of emergency services are not considered in this method (ICBR 2001). 


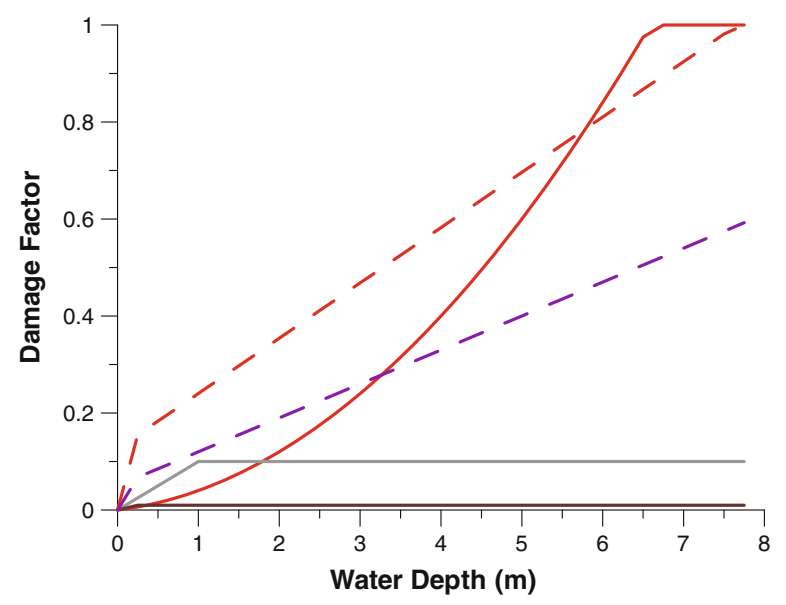

Rhine Atlas curves (DM1)

- Settlement and Industry (immobile)

_ Traffic (immobile and mobile)

Agriculture and Forestry

- - Settlement (mobile)

- Industry (mobile)

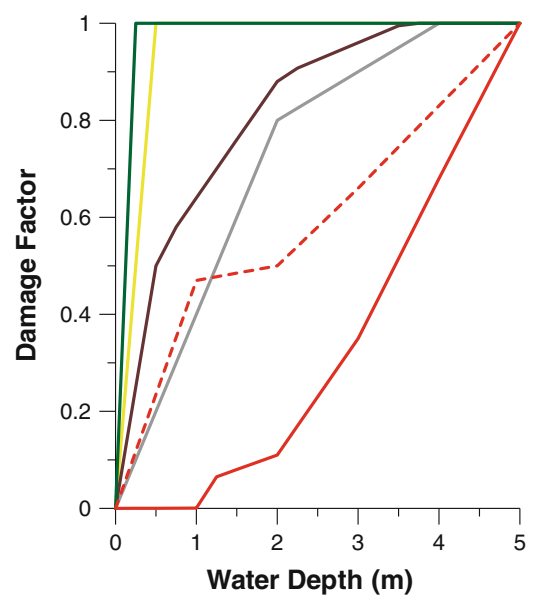

Flemish Method curves (DM2)

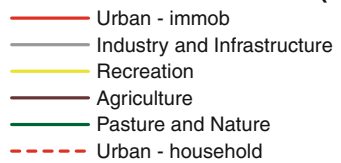

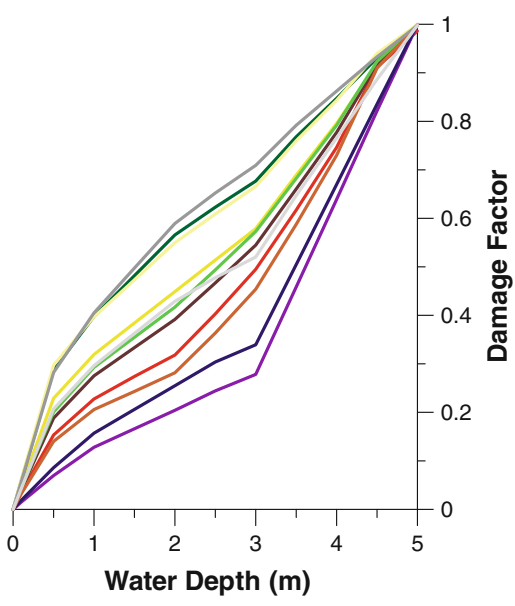

Netherlands Later curves (DM3)

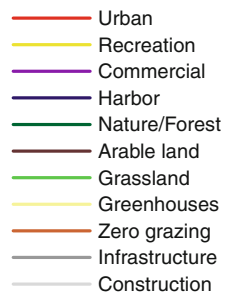

Fig. 4 Depth-damage curves from the Rhine Atlas (ICBR 2001), Flemish Method (Vanneuville et al. 2006) and the Netherlands Later study (Klijn et al. 2007)

\subsubsection{Flemish method (DM2)}

The second damage model used has been developed by Vanneuville et al. (2006) and calculates flood losses based on both land-use classes and some objects. Land-use information is taken from the CORINE database as well as from a national database. The 
Table 2 Damage classes and the corresponding value of elements at risk from the different DMs used in this study

\begin{tabular}{|c|c|c|c|c|c|c|}
\hline $\begin{array}{l}\text { Rhine Atlas } \\
\text { (DM1) }\end{array}$ & $\begin{array}{l}\text { Value of elements } \\
\text { at risk }\left(€ / \mathrm{m}^{2}\right)\end{array}$ & $\begin{array}{l}\text { Flemish } \\
\text { method (DM2) }\end{array}$ & $\begin{array}{l}\text { Value of } \\
\text { elements at } \\
\text { risk }\left(€ / \mathrm{m}^{2}\right)\end{array}$ & $\begin{array}{l}\text { Netherlands } \\
\text { Later (DM3) }\end{array}$ & $\begin{array}{l}\text { Value of } \\
\text { elements a } \\
\text { risk }\left(€ / \mathrm{m}^{2}\right.\end{array}$ & \\
\hline Residential & 252 & Residential 1 & $\begin{array}{lll}900 & 590 \quad 1\end{array}$ & Residential-high $\rho$ & $910 \quad 595$ & 1 \\
\hline Equipment & 59 & Residential 2 & $400 \quad \mid \quad 540$ & Residential-low $\rho$ & 400 & 572 \\
\hline Industry & 262 & Residential 3 & $\begin{array}{lll}100 & 100 \quad \text { I }\end{array}$ & Residential—rural & $380 \quad 380$ & 1 \\
\hline Equipment & 87 & Household & $\begin{array}{l}50 \% \text { of } \\
\text { residential } \\
\text { damage }\end{array}$ & Recreation & 30 & \\
\hline Infrastructure & 266 & Industry & 100 & Commercial & 600 & \\
\hline Equipment & 2 & Infrastructure & 100 & Sea harbour & 500 & \\
\hline Agriculture & 7 & Recreation & 0.03 & Nature/forest & 20 & \\
\hline Forest & 1 & Agriculture & 0.5 & Arable land & 20 & \\
\hline \multirow[t]{6}{*}{ Other } & 0 & Pasture & 0.08 & Grassland & 10 & \\
\hline & & Nature/forest & 0 & Greenhouses & 70 & \\
\hline & & Water & 0 & Zero grazing & 80 & \\
\hline & & & & Infrastructure & 190 & \\
\hline & & & & Building lot & 130 & \\
\hline & & & & Water & 0 & \\
\hline
\end{tabular}

The damage values in the merged cells of DM2 and DM3 correspond to the weighted values of elements at risk of the aggregated residential categories

above-mentioned data are supplemented by line elements (roads, railroads) and point elements (churches, power plants, schools, stations, hospitals, etc.) to enhance the accuracy of the assessment. These line elements have not been used in our analysis as it would hamper the comparison between land-use maps. As a result, the absolute estimates for flood damages using the DM2 configuration will probably be somewhat lower when compared to the original method. Vanneuville et al. (2006) use market values to derive the value of elements at risk. An additional factor on top of the direct damages is used to represent indirect damages for some land-use classes (representing e.g. cleaning costs, production losses). DM2 uses damages per square metre, similar to DM1, except for the residential damage category that uses a value of $€ 100,000 /$ house. In this study, we do not use the detailed method but only the 11 land-use categories that were distinguished (Table 2) resulting in 11, synthetically created, depth-damage curves (Fig. 4). Three residential classes based on different densities have been distinguished in this study, using densities of 90, 40 and 10 houses per hectare.

\subsubsection{Netherlands Later (DM3)}

The Netherlands Later method is a derivative of the HIS-SSM (Kok et al. 2005) to allow for changes in land use in the assessment (which is not possible with the HIS-SSM itself). It has been developed by Klijn et al. (2007) and distinguishes 14 damage categories, including three residential classes on a resolution of 100 by $100 \mathrm{~m}^{2}$ (Table 2). The depthdamage curves and values of elements at risk have been derived from HIS-SSM output for various uniform inundation depths. The HIS-SSM damages, and thus the Netherlands Later 
curves and values, are based on market values (Briene et al. 2002), and the curves have been derived using a limited amount of damage data and expert judgement (Meyer and Messner 2005).

As HIS-SSM damages include about $5 \%$ of indirect damages such as business interruption, traffic interruption and loss of crops (Wouters 2005), the Netherlands Later estimates include this as well.

\section{Results and discussion}

Table 3 shows the results of damage calculations in billions of euros using all combinations of inundation depth, land-use databases and damage models. In the following sections, the influence of the components on the final damage estimate will be discussed (Sects. 4.1-4.3). This sensitivity of the damage calculation to a certain component is presented as a factor, which is calculated by dividing the highest by the lowest damage estimate resulting from the variation in the component, keeping the other components equal. This factor denotes how far off an estimate can be. For example, a factor 2 means that the estimate could be halve or double as well. After discussing the influence of the components, absolute and proportional changes in flood damages between situations with different water depths are calculated and compared in Sect. 4.4.

\subsection{Land use}

Table 3 shows that the variation in absolute flood damage estimates using different landuse maps are relatively small. Overall, the relative differences between the maximum and minimum flood damages range from a factor 1.14 (in DM3, e.g. €9.01bn/€7.89bn) to just under 1.21 (DM1 and DM2). These differences can partly be explained by the number of urban cells present in the different land-use maps (more cells mean higher flood damage). The geographical position of such cells may also play a role, as some land-use maps have, for instance, less urban cells in the flooded area or in areas with lower inundation depths.

Furthermore, it is also interesting to see how much the individual land-use classes, and in particular the urban land-use classes, contribute to the total flood damage (Fig. 5). The residential category has the largest contribution and accounts for $60-95 \%$ of the total damages, averaging at $81 \%$ with a standard deviation of $10 \%$. This range is the result of the use of different DMs and different land-use databases. DM2 and land-use maps that make no distinction between residential and commercial/industrial land use (LGN4 and Top10) account for the highest contribution of the residential damage category. The latter follows logically since an aggregated class of industrial land use and residential land use is a much larger class in terms of area and hence damage. Between the DMs, the main difference in contribution to the total damages lies in the agricultural damage category, which has a very significant contribution in DM3 (14\% on average) but is negligible in the other two.

\subsection{Damage models}

The variation in total damage estimates between the damage models (DMs) is quite high. Comparing the last row with the other rows in Table 3 shows that while damages estimated using DM2 and DM3 are quite similar in absolute terms, DM1 damage estimates are about a factor 4 lower. As residential damages are the main contributor to the total damages (see Fig. 5), this difference can be explained by differences between the DMs in terms of the 


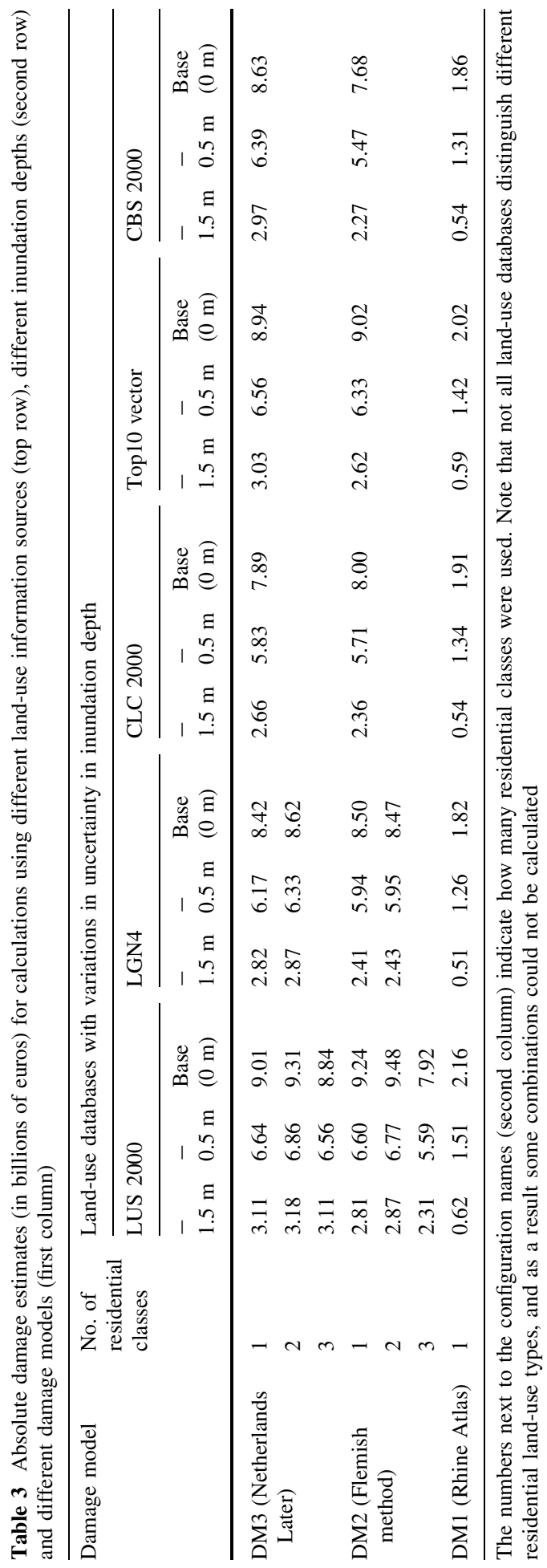




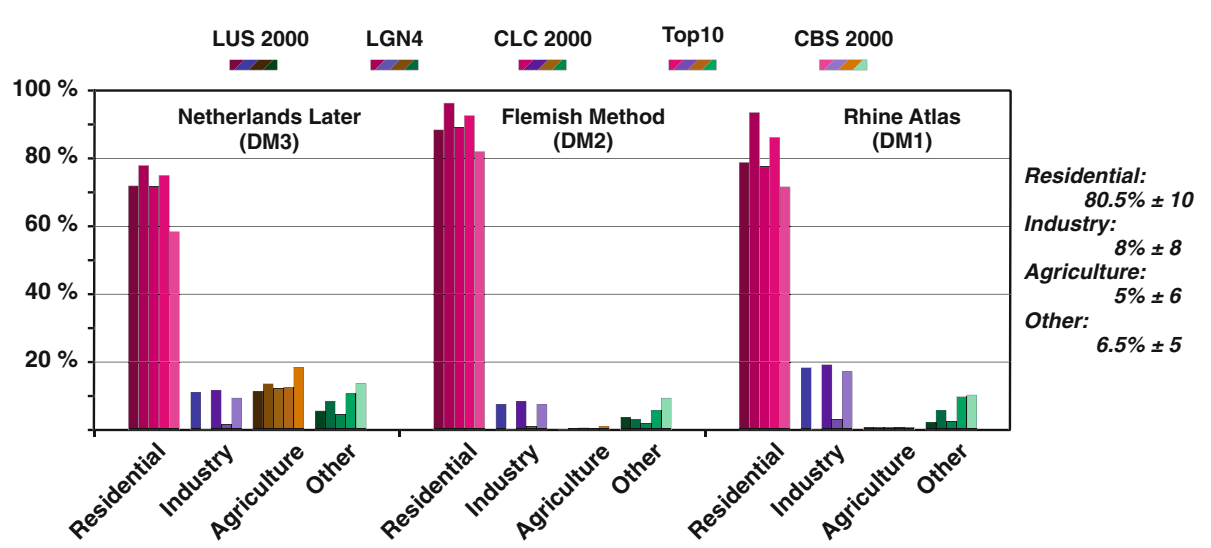

Fig. 5 Contribution of land-use classes to the total estimated flood damages using different DMs and landuse databases

depth-damage curve (component 3) and the values of elements at risk (component 4) of residential land use. For example, Table 2 shows that the values of elements at risk for residential land use in DM1 are about half $\left(252+59=311 € / \mathrm{m}^{2}\right)$ of that of DM2 $(540 € /$ $\left.\mathrm{m}^{2}\right)$ and DM3 $\left(572 € / \mathrm{m}^{2}\right)$, which would explain a factor 2 difference in residential damages between the DMs. Similarly, when comparing the shapes of the residential damage curves of DM1, DM2 and DM3 (Fig. 4), it becomes clear that the residential curves of DM2 and DM3 reach almost $100 \%$ damage at $4.5 \mathrm{~m}$ inundation depth, where the residential curves of DM1 only yield about $50 \%$ at that same inundation depth. This would result in another factor 2 difference between the residential damages in DM1 compared with DM2 and DM3. These two differences combined would thus result in a factor 4 difference between the absolute damage estimates of DM1 and DMs 2 and 3.

Several reasons can be thought of that could explain the differences in these two components between the damage models. With respect to the values of elements at risk, DM1 differs from DM2 and DM3 because indirect damages, like costs resulting from emergency services (e.g. evacuation) or business interruption, are not taken into account. The share of these indirect damages in DM2 and DM3 is, however, limited (around 5-7\%), and therefore this difference in approach is not enough to explain the large difference by itself. Significant differences can occur in the estimation of value at risk when full replacement values are taken instead of actual values as full replacement values are generally larger compared to actual value (Messner et al. 2007; Penning-Rowsell et al. 2005). Both DM2 and DM3 use market values (which are actual and not full replacement values) to derive values for properties at risk. For DM1, the values of elements at risk are derived from official data on property values from four Bundesländer (IKSR 2001). Both DM2 and DM3 use property values of around 100,000 €/property. When this is compared to the value per $\mathrm{m}^{2}$ in DM1 $(252 € / \mathrm{m} 2)$, one arrives at an average density of dwellings of about 25 per hectare of residential land use, which is on the low side but not an unrealistic number. There seems to be a larger discrepancy in the assessment of the value of inventory goods. In DM1, this is $59 € / \mathrm{m}^{2}$, or about $23 \%$ of the value of the property itself. In DM2, the value attributed to inventory is set on $50 \%$ of the property value and in DM3 even almost $70 \%$. A possible reason behind this discrepancy may be that the figures used in DM2 and DM3 for the value of inventory are based on data from insurance companies, who generally work with replacement values. 
The difference in the slope of the residential depth-damage curve between DM1 and DM2 and DM3 is not as easy to explain. All damage models combine expert judgement with available data on flood damages, though DM1 probably uses the most empirical data. The empirical data show, however, considerable uncertainty, as shown by Merz et al. (2004, Fig. 4). Differences in the procedure to derive depth-damage functions by experts and the variation in the underlying empirical data combined are probably the reason for the discrepancy found between DM1 and DM2 and DM3.

\subsection{Inundation depth}

Absolute differences in damage estimates using different inundation depth adjustments are also substantial. A 0.5-m adjustment in inundation depth, for example, results in a damage estimate that differs at least $€ 0.55 \mathrm{bn}$ (DM1) up to $€ 2.7$ bn (DM2) compared to the estimate using the base water map (Table 3). Overall, a 0.5 -m reduction in inundation depth corresponds to a factor 1.35-1.44 difference in the resulting damage estimate. An adjustment of about $25 \mathrm{~cm}$ yields the same variation in estimated damages as is found between the different land-use databases (about a factor 1.2). A variation in inundation depth of more than $1 \mathrm{~m}(0.95 \mathrm{~m}$ using DM1 to $1.1 \mathrm{~m}$ using DM3 to be more exact) is necessary to cause a factor 2 difference in the total damage estimate. This is a similar variation as the effect of the value of elements at risk or the depth-damage curve on the final damage estimate. A variation in inundation depth of more than $1.5 \mathrm{~m}$ is necessary to cause a factor 4 difference, which corresponds with the combined effect of the value of elements at risk and the depthdamage curve. Such uncertainty in inundation depth (with an uncertainty range just as large as the mean) seems unrealistically high as, for instance, Hall et al. (2005b) showed that the standard deviation of inundation depth in downstream areas with relatively simple topography (like our case study area) is about one-fifth of the mean inundation depth. It can therefore be concluded that the choice and quality of the damage model components have a larger influence on the damage estimate than the uncertainty in the hydrological component. This observation is in line with the findings of Apel et al. (2009), who show that the choice of flood loss model (i.e. components 3 and 4) is a much more important contributing factor to the resulting risk estimate than the choice of hazard model (i.e. the hydrological component).

\subsection{Absolute and proportional changes}

In some flood damage assessments, the change in damages compared to a baseline situation (usually the present situation) is considered (e.g. MNP 2007; Hall et al. 2005a). This allows to estimate the effect of certain management measures, land-use changes or the impact of climate change on future flood damages (e.g. Klijn et al. 2007). Any avoided damages due to management measures can then be included in a cost-benefit analysis to evaluate the net benefit of such measures (Brouwer and Kind 2005; Pearce and Smale 2005; Heidari 2009; Miyata and Abe 1994).

Table 4 shows absolute and proportional changes in the damage estimate per $10-\mathrm{cm}$ change in inundation depth. This has been calculated by taking the difference between flood damage estimations using the same land use and DM, but with one having $10 \mathrm{~cm}$ lower inundation depth compared to the other. This has been done for all combinations of damage models and land-use maps over a range of inundation depths from $-0.5 \mathrm{~m}$ to 0 (the base situation). The absolute changes (columns two to four) have been divided by the corresponding damage estimate using the base inundation map to derive proportional 
Table 4 Absolute and proportional changes in damage estimates per $10 \mathrm{~cm}$ inundation depth between different DMs and land-use maps

\begin{tabular}{|c|c|c|c|c|c|c|c|c|c|c|}
\hline & \multicolumn{5}{|c|}{$\begin{array}{l}\text { Absolute damage change }(€ \mathrm{bn} / 10 \mathrm{~cm} \\
\text { inundation depth) }\end{array}$} & \multicolumn{5}{|c|}{$\begin{array}{l}\text { Proportional damage change (\% of base damage/ } \\
10 \mathrm{~cm} \text { inundation depth) }\end{array}$} \\
\hline & DM1 & DM2 & DM3 & Factor & Avg. & DM1 & DM2 & DM3 & Factor & Avg. \\
\hline CLC & 0.12 & 0.47 & 0.42 & 4.02 & I & $6.1 \%$ & $5.8 \%$ & $5.3 \%$ & 1.15 & I \\
\hline RS & 0.13 & 0.54 & 0.48 & 4.07 & I & $6.1 \%$ & $5.8 \%$ & $5.3 \%$ & 1.14 & 1 \\
\hline LGN4 & 0.11 & 0.52 & 0.46 & 4.62 & 4.26 & $6.2 \%$ & $6.2 \%$ & $5.4 \%$ & 1.15 & 1.14 \\
\hline Top10 & 0.12 & 0.55 & 0.48 & 4.51 & I & $6.0 \%$ & $6.1 \%$ & $5.4 \%$ & 1.12 & I \\
\hline CBS & 0.11 & 0.45 & 0.46 & 4.09 & 1 & $6.0 \%$ & $5.9 \%$ & $5.3 \%$ & 1.14 & 1 \\
\hline Factor & 1.18 & 1.22 & 1.16 & & & 1.04 & 1.06 & 1.03 & & \\
\hline Average & - & 1.19 & - & & & - & 1.04 & - & & \\
\hline
\end{tabular}

The numbers are averages over the range $-0.5 \mathrm{~m}$ to 0 . The changes in estimated damage have been divided by the damage estimated using the base damage map to derive the proportional change. The factors are calculated by dividing the highest estimate in the range by the lowest estimate in the range

changes (columns six to eight). Factors denoting the variation between land-use maps (see the last two rows) and between damage models (see columns 5-6 and the last two) have been calculated by dividing the maximum estimate by the minimum estimate.

When comparing the average absolute damage changes between different DMs (see factors in columns 5-6), it becomes clear that, similar to the absolute estimates themselves (see Sect. 4.2), these changes in absolute estimates also differ roughly a factor 4 (4.26 on average). The maximum deviation caused by different land-use maps is on average a factor 1.19, again similar to the deviation in the absolute damage estimates (see Sect. 4.1). Compared to the absolute change in damage over inundation depth, the proportional change in damages per $10 \mathrm{~cm}$ inundation depth varies substantially less (Table 4, right part). This proportional change in flood damages over inundation depth is on average almost $6 \%$ (of the damage estimated using the base inundation depth) per $10 \mathrm{~cm}$ inundation depth change. The degree to which this number varies as a result of different DMs is small (factor 1.14), and variation in damage estimates due to different land-use maps is negligible (factor 1.04).

\section{Conclusions}

Our results indicate that the level of uncertainty inherent in estimated flood damage figures resulting from uncertainties underlying the four main components of a damage assessment is substantial. The contribution of the different components to the uncertainty in the final damage estimate and thus the sensitivity of flood damage assessment are illustrated in Fig. 6.

Adding up the effects of the different components (by multiplying the factors), the total uncertainty surrounding a flood damage estimate becomes substantial. When assuming that uncertainty in the inundation depths amounts to about $25 \mathrm{~cm}(\sim 15 \%$ of the mean inundation depth), the total range of outcomes can vary up to a factor 5-6 (factor $4 \times 1.2 \times 1.2$ ). In other words, the lowest estimate is 5-6 times lower than the highest estimate. This is mainly the result of large uncertainties in the determination of the value of elements at risk and the depth-damage curves, which jointly account for about a 
Fig. 6 Diagram showing the variation in the absolute damage estimate as a result of uncertainty in different input parameters of a damage assessment

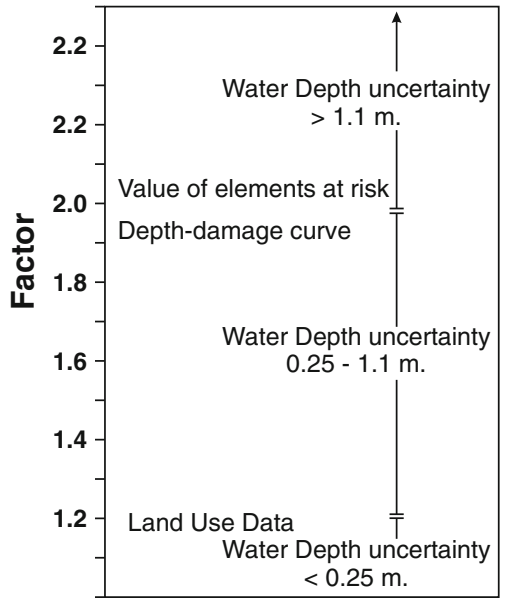

factor 4 variation. This is especially important for residential land use as it makes up around $80 \%$ of the total damages. Uncertainty in land-use data has a modest effect on the resulting damage estimate (about a factor 1.2), similar to the effect from a variation in inundation depth of $\sim 25 \mathrm{~cm}$. In order for the hydrological component to cause a factor 2 variation in damage estimates (equal to the value of elements at risk or the depth-damage curve), the range of inundation depth should be about $1 \mathrm{~m}$. A range in inundation depth of more than $1.5 \mathrm{~m}$ is necessary to cause a factor 4 variation in damage estimates, which would be comparable to the differences in damage estimations between the DMs.

As uncertainty in the inundation depth information of such a magnitude is unlikely (the uncertainty would then have to be larger than the mean), it can be concluded that the damage model is the most important contributor to uncertainty in flood damage estimates. The quality of the depth-damage curve and the values of elements at risk for especially the residential land-use class, and to a lesser extent the industry land-use class, are thus of critical importance in flood damage assessments. Correspondingly, from a flood damage assessment perspective, these components deserve considerable attention in research, whereas at the moment most efforts in flood risk assessments focus on the hydrological component.

While our results concern a single dike ring in the Netherlands, similar assessments in other areas will, given the nature of the input data, likely be subject to similar uncertainties in input data. Because of the large uncertainty surrounding flood damage estimates, absolute damage figures, or changes in absolute damage figures, should be used cautiously in any assessment. Proportional changes in flood damages (changes as a percentage of a reference situation), on the other hand, have much lower uncertainty and statements about proportional damage increases or decreases can consequently be made with a satisfying degree of certainty. Assuming that the uncertainty in inundation depth is no higher than $25 \mathrm{~cm}$, the total variation that can be expected surrounding an estimate for a proportional change in damages is around a factor 1.25 in our case study area (compared to a factor 6 with absolute damage estimates).

Our study addressed uncertainty surrounding flood damage estimates in a general setting. For future research, it would be very interesting to focus on uncertainty related to different scenarios (dike breach scenarios, climate change scenarios and socio-economic scenarios) and how variation between scenarios relates to current uncertainties. 
Acknowledgments The authors would like to thank Dr. Sergiy Vorogushyn and one anonymous reviewer for their constructive reviews. The authors would also like to thank Karin de Bruijn and Laurens Bouwer for their valuable comments on earlier versions of this manuscript. This research has been performed within the BSIK-LANDS project of the Dutch national research programme "Climate Changes Spatial Planning".

Open Access This article is distributed under the terms of the Creative Commons Attribution Noncommercial License which permits any noncommercial use, distribution, and reproduction in any medium, provided the original author(s) and source are credited.

\section{References}

Aerts J, Sprong T, Bannink BA (2008) Aandacht voor Veiligheid, vol 009/2008. Leven met Water, Klimaat voor Ruimte, DG Water, pp 3-196

Apel H, Thieken AH, Merz B, Bloschl G (2004) Flood risk assessment and associated uncertainty. Nat Hazards Earth Syst Sci 4(2):295-308. doi:10.5194/nhess-4-295-2004

Apel H, Thieken AH, Merz B, Bloschl G (2006) A probabilistic modelling system for assessing flood risks. Nat Hazards 38(1-2):79-100. doi:10.1007/s11069-005-8603-7

Apel H, Merz B, Thieken AH (2008) Quantification of uncertainties in flood risk assessments. Int J River Basin Manag 6(2):149-162

Apel H, Aronica GT, Kreibich H, Thieken AH (2009) Flood risk analyses-how detailed do we need to be? Nat Hazards 49(1):79-98. doi:10.1007/s11069-008-9277-8

Bouwer LM, Bubeck P, Wagtendonk AJ, Aerts JCJH (2009) Inundation scenarios for flood damage evaluation in polder areas. Nat Hazards Earth Syst Sci 9(6):1995-2007. doi:10.5194/nhess-9-1995-2009

Briene M, Koppert S, Koopman A, Verkennis A (2002) Financiële onderbouwing kengetallen hoogwaterschade, vol I7435. Netherlands Economic Institute (NEI), Rotterdam, pp 1-33

Brinke WBMt, Bannink BA (2004) Risico's in bedijkte termen: een thematische evaluatie van het Nederlandse veiligheidsbeleid tegen overstromen. RIVM rapport, vol 500799002. Beleidsmonitor Water. RIVM, Bilthoven, pp 1-242

Brouwer R, Kind JM (2005) Cost-benefit analysis and flood control policy in the Netherlands. In: Brouwer R, Pearce D (eds) Cost-benefit analysis and water resources management, vol 5. Edward Elgar Publishing, Ann Arbor, pp 71-91

CBS (2000) Bestand bodemgebruik. (2000). Den Haag, Centraal Bureau voor de Statistiek

de Moel H, van Alphen J, Aerts JCJH (2009) Flood maps in Europe-methods, availability and use. Nat Hazards Earth Syst Sci 9(2):289-301. doi:10.5194/nhess-9-289-2009

de Wit AJW (2003) Land use mapping and monitoring in the Netherlands using remote sensing data. In: Geoscience and remote sensing symposium, 21-25 July, IEEE international, Toulouse

de Wit AJW, Clevers JGPW (2004) Efficiency and accuracy of per-field classification for operational crop mapping. Int J Remote Sens 25(20):4091-4112. doi:10.1080/01431160310001619580

DKKV (2004) Flood risk reduction in Germany-lessons learned from the 2002 disaster in the Elbe region. Report 29e. Deutsches Komitee für Katastrophenvorsorge e. V. (DKKV), Bonn

Dutta D, Herath S, Musiakec K (2003) A mathematical model for flood loss estimation. J Hydrol 277(12):24-49. doi:10.1016/S0022-1694(03)00084-2

EEA (2007) CORINE land cover 2000 (CLC2000) 100 m. Version 9, European Environment Agency, Copenhagen, Denmark

EEA, WHO, JRC (2008) Impacts of Europe's changing climate-2008 indicator-based assessment. EEA No 4/2008. European Environment Agency, Copenhagen, Denmark

Egorova R, van Noortwijk JM, Holterman SR (2008) Uncertainty in flood damage estimation. Int J River Basin Manag 6(2):139-148

Hall JW, Sayers PB, Dawson RJ (2005a) National-scale assessment of current and future flood risk in England and Wales. Nat Hazards 36(1-2):147-164. doi:10.1007/s11069-004-4546-7

Hall JW, Tarantola S, Bates PD, Horritt MS (2005b) Distributed sensitivity analysis of flood inundation model calibration. J Hydraul Eng 131(2):117-126. doi:10.1061/(ASCE)0733-9429(2005)131:2(117)

Heidari A (2009) Structural master plan of flood mitigation measures. Nat Hazards Earth Syst Sci 9(1):61-75. doi:10.5194/nhess-9-61-2009

Heuvelink GBM (1998) Error propagation in environmental modelling with GIS. Taylor \& Francis, London, pp $1-127$

Hilferink M, Rietveld P (1999) Land Use Scanner: an integrated GIS model for long term projections of land use in urban and rural areas. J Geogr Syst 1(2):155-177. doi:10.1007/s101090050010 
ICBR (2001) Atlas van het overstromingsgevaar en mogelijke schade bij extreem hoogwater van de Rijn. Koblenz, Internationale Commissie ter Bescherming van de Rijn (ICBR)

IKSR (2001) Ubersichtskarten der Uberschwemmungsgefahrdung und Vermogensschaeden am Rhein, pp $1-44$

Kadaster (2005) TOP10vector. Topografische Dienst Kadaster, Apeldoorn

Klijn F, Baan PJA, De Bruijn KM, Kwadijk J (2007) Overstromingsrisico's in Nederland in een veranderend klimaat, vol Q4290. Delft, Netherlands, WL, Delft hydraulics, pp 1-166

Kok M, Huizinga HJ, Vrouwenvelder ACWM, Barendregt A (2005) Standaardmethode2004—Schade en Slachtoffers als gevolg van overstromingen. DWW-2005-005. RWS Dienst Weg- en Waterbouwkunde

Lekuthai A, Vongvisessomjai S (2001) Intangible flood damage quantification. Water Resour Manag 15(5):343-362. doi:10.1023/A:1014489329348

Merz B, Thieken AH (2009) Flood risk curves and uncertainty bounds. Nat Hazards 51(3):437-458. doi: 10.1007/s11069-009-9452-6

Merz B, Kreibich H, Thieken A, Schmidtke R (2004) Estimation uncertainty of direct monetary flood damage to buildings. Nat Hazards Earth Syst Sci 4(1):153-163. doi:10.5194/nhess-4-153-2004

Merz B, Thieken AH, Gocht M (2007) Flood risk mapping at the local scale: concepts and challenges. In: Advances in natural and technological hazards research, vol 13. Springer, Dordrecht, pp 231-251

Messner F, Pennning Rowsell EC, Green C, Meyer V, Tunstall S M, van der Veen A (2007) Evaluating flood damages: guidance and recommendations on principles and practices, vol T09-06-01, pp 1-178. FLOODsite

Meyer V, Messner F (2005) National flood damage evaluation methods - a review of applied methods in England, the Netherlands, the Czech Republic and Germany. 21/2005. Leipzig, Germany, Department of Economics, Umweltforschungszentrum Leipzig-Halle. UFZ-Discussion Papers

Meyer V, Scheuer S, Haase D (2009) A multicriteria approach for flood risk mapping exemplified at the Mulde river, Germany. Nat Hazards 48(1):17-39

Miyata Y, Abe H (1994) Measuring the effects of a flood-control project-hedonic land price approach. J Environ Manag 42(4):389-401. doi:10.1007/s11069-008-9244-4

MNP (2007) Nederland later-tweede duurzaamheidsverkenning deel fysieke leefomgeving Nederland, vol 500127001/2007. Milieu- en Natuurplanbureau (MNP), Bilthoven, pp 3-122

Munich Re (2005) Weather catastrophes and climate change. München, Münchener RückversicherungsGesellschaft. Knowledge series, pp 2-264

Nascimento N, Baptista M, Silva A, Machado L, Costa de Lima J, Goncalves M, Silva A, Dias R, Machado E (2006) Flood-damage curves: methodological development for the Brazilian context. Water Pract Technol 1(1). doi:10.2166/WPT.2006022

Noack M, Yörük A (2008) Uncertainty in hydrodynamic-numerical modelling of flood areas. Hydrologie und Wasserbewirtschaftung 52(4):173-178

Pearce DW, Smale R (2005) Appraising flood control investments in the UK. In: Brouwer R, Pearce D (eds) Cost-benefit analysis and water resources management, vol 4. Edward Elgar Publishing, Ann Arbor, pp 71-91

Penning-Rowsell EC, Johnson C, Tunstall S, Tapsell S, Morris J, Chatterton J, Green C (2005) The benefits of flood and coastal risk management: a handbook of assessment techniques. Middlesex University Press, Flood Hazard Research Centre

Riedijk A, van Wilgenburg R, Koomen E, Borsboom-van Beurden J (2007) Integrated scenarios of socioeconomic and climate change; a framework for the 'Climate changes Spatial Planning' program. Spinlab Research Memorandum SL-06. Amsterdam, the Netherlands, Vrije Universiteit Amsterdam

Roos A, Van der Geer I (2008) New approaches for flood risk management in the Netherlands. In: Proceedings of the 4th international symposium on flood defence, 6-8 May 2008, Toronto, Canada. Institute of Catastrophic Loss Reduction

RWS-DWW (2005) Flood risks and safety in the Netherlands (Floris). DWW-2006-014

Smith DI (1994) Flood damage estimation-a review of urban stage-damage curves and loss functions. Water SA 20(3):231-238

Tang JCS, Vongvisessomjai S, Sahasakmontri K (1992) Estimation of flood damage cost for Bangkok. Water Resour Manag 6:47-56. doi:10.1007/BF00872187

te Linde AH, Aerts JCJH, Bakker AMR, Kwadijk JCJ (2010) Simulating low-probability peak discharges for the Rhine basin using resampled climate modeling data. Water Resour Res 46:W03512. doi: 10.1029/2009WR007707

Thieken AH, Olschewski A, Kreibich H, Kobsch S, Merz B (2008) Development and evaluation of FLEMOps-a new Flood Loss Estimation MOdel for the private sector. Flood recovery, innovation and response I. WIT Press, pp 315-324 
Tunstall SM, Johnson CL, Pennning Rowsell EC (2004) Flood hazard management in England and Wales: from land drainage to flood risk management. In: Proceedings of the world congress on natural disaster mitigation. New Delhi, India

USACE (2007) Flood damage analysis Santa Maria Levee Project. Los Angelos, United States Army Corps of Engineers Los Angeles District, Economics Section

van Oort PAJ, Bregt AK, de Bruin S, de Wit AJW, Stein A (2004) Spatial variability in classification accuracy of agricultural crops in the Dutch national land-cover database. Int $\mathrm{J}$ Geogr Inf Sci 18(6):611-626. doi:10.1080/13658810410001701969

Vanneuville W, Maddens R, Collard C, Bogaert P, de Maeyer P, Antrop M (2006) Impact op mens en economie t.g.v. overstromingen bekeken in het licht van wijzigende hydraulische condities, omgevingsfactoren en klimatologische omstandigheden, vol MIRA/2006/02. Universiteit Gent, Vakgroep Geografie, Gent, Belgium, pp 3-121

Veerbeek W, Zevenbergen C (2009) Deconstructing urban flood damages: increasing the expressiveness of flood damage models combining a high level of detail with a broad attribute set. J Flood Risk Manag 2(1):45-57. doi:10.1111/j.1753-318X.2009.01021.x

Wind HG, Nierop TM, de Blois CJ, de Kok JL (1999) Analysis of flood damages from the 1993 and 1995 Meuse floods. Water Resour Res 35(11):3459-3465. doi:10.1029/1999WR900192

Wouters K (2005) Veiligheid Nederland in kaart globale schadeberekening. Delft, Dienst Weg- en Waterbouwkunde, Rijkswaterstaat

Wünsch A, Herrmann U, Kreibich H, Thieken AH (2009) The role of disaggregation of asset values in flood loss estimation: a comparison of different modeling approaches at the Mulde River, Germany. Environ Manag 44(3):524-541. doi:10.1007/s00267-009-9335-3 